\title{
Examining Consumer-Purchasing Behaviour Towards Valuable Sportswear Brands: The Social Representation Theory Perspective
}

\author{
Dr. Yahya Manna \\ Jazan University, PO box 114, Jazan 45142, KSA
}

\begin{abstract}
This study examined consumer purchasing behaviour towards valuable sportswear brands from the perspective of social representation theory. The study reveals more purchasing intentions for Adidas than Puma among consumers and e-consumers in Saudi Arabia. The consumer purchasing behaviour is dependent on social representation, attitude, and preferences. Mediating factors for consumer purchasing behaviours include social class, age, gender, education level, and living area. The study further established that customers or e-consumers association with the valuable sportswear of either Adidas or Puma require online or offline stores to build trust, enhance touch, and maximize the experience to inform consumer purchase decision-making. The study recommends proper alignment of the marketing processes with contemporary developments such as e-commerce to resonate with different consumer groups. The Internet has changed the way companies create a brand presence in stores, online shops, or social media. Different customer segments in Saudi Arabia showed diverse consumer purchasing behaviours towards branded t-shirts or shoes of Adidas and Puma. Further studies should focus on purchasing behaviours towards other sportswear brands beyond the Saudi Arabian market.
\end{abstract}

Keywords: Consumer purchasing behaviours; social representation; valuable sportswear brands; online stores; in-stores; e-consumers

DOI: $10.7176 / \mathrm{JMCR} / 60-03$

Publication date:September $30^{\text {th }} 2019$

\section{Introduction}

1.1 Problem Statement and Objective

Consumer purchasing behaviours towards brands is a controversial subject with diversified views. The sportswear industry branding directly affects consumer purchasing behaviour in Saudi Arabia. The firm and brand innovativeness create customer value by mediating the instrumental brand benefits (Kim et al., 2015). The demand for international sportswear brand continues to grow as citizens in Saudi Arabia register high disposable incomes and consciousness about global fashion trend (Abalkhail, 2017). Moreover, consumers of different ages and origins purchase branded products of a certain origin and appeal. Sportswear brands focus on branding efforts that impress the diverse Saudi consumer market. According to Bilgihan (2016), the branding process should encompass an integrated framework of trust, value, and user experience to inform the purchasing of branded products. Sportswear brands use an integrated model for sportswear marketing.

Sportswear brand names serve as social markers, which makes it a crucial part of global sportswear marketing (Ko et al., 2012). Social marking is evident from the companies that have invested in the Saudi Arabia market. Sportswear firms such as Adidas, Puma, Reebok, and Nike have targeted and established a significant market share in the growing Saudi economy. The social marking element is more rampant now that internet retailing is overtaking traditional in-store sales in Saudi Arabia, as telecommunications connectivity reached over 4million connections in 2017 (Abalkhail, 2017). Saudis with active but varying fashion preferences are using e-commerce and brick and mortar stores to purchase their sportswear brands. According to Chi and Kilduff (2011), the success of sportswear marketing depends on brands alignment with price, quality, social, and emotional values. However, studies have given little attention to consumer purchasing behaviours towards sportswear brands in Saudi Arabia.

Numerous studies have tried to examine consumers 'purchasing behaviour in various contexts. Ko et al. (2012) established that sportswear firms map consumer behaviours towards their brands based on lifestyle factors. The study determined that the companies segment consumers according to social followership besides fashion leadership, conspicuous fashion, and sensationalism seeking behaviours. Contrastingly, Tong, and $\mathrm{Su}$ (2014) found that personality of the brands shapes consumer-purchasing behaviours as opposed to psychographic segments. However, Su and Tong (2015) found that brand equity is vital, besides personalities such as sincerity and innovation. The studies focused on sportswear industry in other countries rather than Saudi Arabia. Moreover, there is limited research that has examined consumer purchasing behaviour for valuable sportswear brands.

Euromonitor International (2017) observed reduced sportswear sales in 2016-2017. The trend shows changes in customer purchasing behaviour in a market where customers have embraced global fashion trends 
dominated international brands. Different factors influence purchasing behaviours towards sportswear brands in Saudi Arabia, including culture, legal restrictions, Islamic beliefs, social class, age, and gender. Studies have not established factors associated with the normal consumers and e-consumers of valuable sportswear brands in Saudi Arabia. Through a comparative study of the perceptions of regular consumers and e-consumers, this article will assess consumer purchasing behaviour towards valuable sportswear brands in the Saudi Arabia context by the use of social representation theory.

\subsection{Theoretical Background}

Sportswear firms such as Adidas, Puma, Nike, and Reebok have invested in the growing Saudi economy. The country opened a platform for foreign investment to reduce reliance on oil exports. Abalkhail (2017), associates the high demand for valuable sportswear products with the increasing high disposable incomes and fashion consciousness among both men and women. Similarly, sportswear brands use in-stores and e-commerce following the evolution of the telecommunication industry in the kingdom. Consequently, the purchasing patterns for the sportswear brands vary between consumers and e-consumers and exhibits tenets of social representation theory.

The theory entails processes of shared mean-making that leads to mutual cognitions, which produce social bonds. SRT explains the changing collective thinking, ideological struggle, strong feelings, and conflicts among groups or individuals in a particular society. SRT addresses the processes where consumers and e-consumers create a collective representation towards a certain brand. However, the representations vary with age, sex, gender, or religion, which implies that e-consumers and consumers could demonstrate varying attitudes towards valuable sportswear brands. Behaviour is a product of reconstruction due to individuals or groups' tendency to conceptualise based on the environment around them.

Consumers respond to normative beliefs and motivation to comply guided by the branding of a particular product or service. Hoyer, MacInnis, and Pieters (2013) established that brand representation influenced consumers' purchase behaviour and attitude, as well as the perceived brand association or quality of the brand. Zeithaml (1988) argued that the perceived value of brands depended on the overall representation. According to Sheth and Mittal (2004), choice behaviour depends on the perceived epistemic, functional, social, emotional, and conditional values. Tsordia, Papadimitriou, and Parganas (2017) associated perceived quality, brand engagement, and loyalty defined purchasing behaviours for the sponsor's product after conducting 222 surveys. However, Wang, Pelton, and Hsu (2018) found from a study of Taiwanese consumers that consumers' brand awareness, emotional, and attitudinal factors determine the subsequent purchases intentions.

\section{Literature Review}

Brand names associated with sports sponsorship increasing purchase intentions in the target market. Biscaia et al. (2013) established a connection between brand names and loyalty when they studied the attitudinal determinants of fan loyalty as well as reactionary behaviours towards sports sponsors. Su and Tong (2015) agreed with Biscaia, et al. (2013) on sponsorships increasing purchasing intentions and loyalty when they studied branding from the perspective of the sportswear industry. However, sportswear brands should build equity and image to depict traits such as competence, innovation, activity, sincerity, excitement, and ruggedness. Huang and Huddleston (2009), Su and Tong (2015) determined that brand personality was the best way to shape purchase intentions in the competitive sportswear market.

Brands in the sportswear industry should identify with the audience for them to patronise the purchasing behaviours. Herrmann, Kacha, and Derbaix (2016) observed from 2540 fans and non-fans that sales-oriented sponsorship builds a brand and audience identification. Correspondingly, the purchasing behaviours change with the way firms' structure their awareness campaigns to foster recognition and limit recalls from loyal as well as casual fans (Biscaia, Correia, Ross, \& Rosado, 2014; Olbrich \& Holsing, 2011). However, the eventual purchasing patterns depend on the creation of self-congruity for symbolic co-branded products as opposed to the sponsorship effectiveness (Mazodier \& Merunka, 2014; Shukla, 2009). The study examines Adidas and Puma brands whose companies have adopted varied campaigns in the Saudi Arabian markets. According to Mazodier and Merunka (2014), the drivers of purchases go beyond the attitudes.

According to Suki (2013), the brand name is one of the constituent drivers of purchase behaviours besides prices, product features, prices, and social influence. However, the research established that brand name and social influence had a significant effect on the increasing demand for smartphone brands in the Malaysian market. Furthermore, the purchasing intentions increase with the luxury element attached to a product (Godey et al., 2012; Kim \& Ko, 2010). The brand and country of origin inform the customers' decision to purchase the final product. Hence, purchasing behaviour depends on the brand name, loyalty created through sponsorships, and the attitudes created through well-thought branding campaigns. Godey et al. (2012) found that the purchasing decision-criteria of a given brand depend on the maturity of the luxury market. The study examines a growing sportswear apparel market of Saudi Arabia. 
The religion-based motivation influences the consumers' behaviours towards brand names, loyalty, and image. Abosag and Farah (2014) addressed religious animosity as an imperative element that could define how a brand name affects purchasing intentions. The study aligned with the Islam-dominant traditions in Saudi Arabia that have determined the way firms such as Adidas and Puma brand their sportswear products. The religious beliefs could influence consumer judgment towards brands and eventual purchasing process. Contrastingly, Darrat (2011) observed that cultural animosity could arise in the Middle East and impede the branding process and subsequent purchasing intentions. The research revealed the link between a brand name and cultural or religious of the customers purchasing it in the market. However, brand image determines the purchase intentions for apparel sold online.

According to Aghekyan-Simonian et al. (2012), brand image and online store image influence the online purchasing intentions for the identified apparel. The physical examination of the apparel prior to buying is as important as the virtual assessment of the brands. The study examines the perspective of Adidas and Puma whose customers have utilised both online and physical stores to purchase brands. However, AghekyanSimonian et al. (2012) argued that online shopping could increase the risk perceptions associated with a given brand and subsequent purchase intentions. Additionally, the customer purchase decisions for apparel sold online depend on the touchpoints created by the retail (Dabholkar \& Sheng, 2012; Herhausen, Binder, Schoegel, \& Herrmann, 2015). The touchpoints could be on social media sites and e-shopping site, which lead to satisfaction and loyalty intention with the brand (Lim, Al-Aali, \& Heinrichs, 2014; Blasco-Arcas, Hernandez-Ortega, \& Jimenez-Martinez, 2014,). Sportswear products such as Adidas and Puma have capitalised on the social representation aspect to improve intention to purchase the valuable t-shirts through branding.

Busnaina (2014) found that marketing fashion products in the Arab world necessitate firms to consider adaptive aspects rather than brand identity. The study focused on popular products such as Levi's, Burberry, H\&M, and GUESS as opposed to the valuable sportswear brands. Correspondingly, the country of origin influences the way Arab consumers perceive the personality and image of the brand. Prendergast, Tsang, and Chan (2010) found the country of origin increase the level of personal involvement with the brands and subsequent purchase intentions. The studies addressed the unique nature of the Saudi market where the sportswear brands have carved commendable niche despite longstanding negative perceptions about Western fashion brands (Al-Ghaith, Sanzogni, \& Sandhu, 2010; Azam, 2015). On the other hand, consumer behaviours changes with the social representation aspects of a particular brand.

Khare et al. (2011) found that consumers were susceptible to interpersonal influences, collective self-esteem issues, and the age of fashion clothing involvement. The representation elements had a normative influence on the customers' intention to associate with global fashion brands in India. The subsequent purchase decisions depend on social information cues (Cheung, Xiao, \& Liu, 2014; Park \& Lee, 2009). Consumer engagement and expertise should have a moderating effect on consumer purchasing behaviours towards brands that sell to the online community. However, gender moderates materialism and fashion clothing involvement more than the actions taken by the firms do (Handa \& Khare, 2011; Rahman et al., 2018). Hence, collective behaviour arises from gender and the online communities, which shape collective purchasing behaviours towards certain sportswear or fashion brands.

Customers can conceptualise and reconstruct an experience with a brand based on psychological and cultural intuitions (Eng \& Bogaert, 2010; Reimann, Castaño, Zaichkowsky, \& Bechara, 2012). Psychological and cultural perceptions should inform the homogenous luxury preference for status and social identity as conceptualised in SRT. Consequently, status and identity formed through psychological or cultural fronts lead to brand community formations. Kilambi, Laroche, and Richard (2013) established that persuasion and rhetorical actions through branding are necessary to direct, grow, and oversee the maintenance of brand communities. Hence, sportswear brands depend on the relationship marketing initiatives to enhance their brand equity. Settings such as Saudi Arabia demand brand revitalisation to enhance appropriation, diffusion, and convergence (Azam, 2015; Närvänen \& Goulding, 2016). Consumer purchase intentions increase when revitalisation aligns with collective behaviours towards brands.

\section{Methodology}

The study utilised an exploratory as opposed to an explanatory approach. The tenets of grounded theory guided the research. The ground theory views research as the source of insights to confirm or grow a theory (Urquhart, 2012). The research utilised logical reasoning to confirm the social representation theory. The grounded theory provides a methodical process for developing a model that explains the actions, procedures, and concepts about the phenomena under scrutiny (Birks \& Mills, 2015). Subsequently, the building of an SRT theory necessitates the collection of preliminary data to facilitate the description and development of hypotheses or data collection tools. The qualitative aspect of the research entailed a review of the literature covering the consumer purchasing behaviours towards valuable sportswear brands of Adidas and Puma. The outcomes of the preliminary study helped to develop the questionnaire used to collect data from the respondents. A non-probability sampling 
method was appropriate for exploratory research.

A purposive sampling method enabled the selection of the appropriate sample for the study. The method facilitates the selection of a representative sample based on the characteristics of the target population (Lapan, Quartaroli, \& Riemer, 2011). The study selected consumers and e-consumers who shop valuable sportswear brands of Adidas and Puma. The primary research targeted 1200 customers and selected a sample of 300 consumers who have purchased branded t-shirts from Adidas and Puma. The qualitative approach informed the development of the questionnaire used to collect data from respondents in Jeddah, Riyadh, and Dammam. A questionnaire is appropriate for qualitative research that aims to understand the thought process and experiences of various respondents (Patten, 2016). E-consumers and regular consumers of Adidas and Puma offered insights, which the study strengthened using secondary sources. The questionnaire helped to gather true and transparent perspectives of consumer purchasing behaviours towards valuable sportswear brands. The in-depth data analysis with IBM-SPSS helped to organise and analyse the data gathered through the questionnaires.

\section{Findings}

Respondents from different age groups responded to the questionnaires and interviews, as shown in Table 1 below. The age groups comprised customers who have bought t-shirts and shoes from Adidas and Puma. More male than female respondents participated in the study. The consumers and e-consumers of Puma and Adidas live within and out of the city. The respondents possess different education qualifications from the universities in Jeddah, Riyadh, and Dammam.

Table 1: Demographic Profile of Respondents

\begin{tabular}{|l|c|c|c|c|}
\hline PROFILE & \multicolumn{2}{|c|}{ ADIDAS } & \multicolumn{2}{c|}{ PUMA } \\
\hline AGE GROUPS & FREQUENCY & PERCENTAGE & FREQUENCY & PERCENTAGE \\
\hline 17- 27 years & 247 & & & 45.5 \\
\hline 28-37 years & 168 & 44.0 & 171 & 31.3 \\
\hline $38-47$ years & 69 & 29.9 & 58 & 10.6 \\
\hline $48-57$ years & 49 & 12.3 & 49 & 9.0 \\
\hline 58 years or older & 28 & 8.7 & 20 & 3.7 \\
\hline GENDER & & 5.0 & & 66.5 \\
\hline Male & 366 & & 364 & 33.5 \\
\hline Female & 195 & 65.2 & 183 & 67.3 \\
\hline RESIDENCE & 327 & 34.8 & & 32.7 \\
\hline City & 234 & 58.3 & 179 & 29.1 \\
\hline Out of city & & 41.7 & & 22.3 \\
\hline EDUCATION LEVEL & 184 & 32.8 & 159 & 38.4 \\
\hline High school graduate & 73 & 13.0 & 122 & 10.2 \\
\hline Associate degree & 243 & 43.3 & 56 & \\
\hline Bachelor's degree & 61 & 10.9 & & \\
\hline Master's and higher & & & & \\
\hline
\end{tabular}

\subsection{Social Representation}

Correlation tests showed a relationship between social representation and preference. The coefficient of correlation equalled 0.551 , and the p-value was 0.000 , which is less than 0.05 . The social representation and preference for Adidas sportswear brands (t-shirts and shoes) were higher than Puma among e-consumers and consumers in Saudi Arabia at a significance level of $\alpha=0.05$. The tests incorporated different aspects of social representations for valuable sportswear brands of Adidas. The aspects included expensive, robustness, colourfulness, fashionable, youthfulness, logo, quality, convenience, efficiency, technical, variety, and effectiveness. The social representation and preference of Puma sportswear brands had a moderate effect on the consumers and e-consumers based on a significance level of $\alpha=0.05$.

\subsection{Attitude, Behaviour, and Social Media}

The positive attitude, behavioural, preference, and presence on social for Adidas brands were higher than Puma based on the tests carried from the data collected in the field (See Tables 2 and 3). The results from one-sample t-test were based on a significance level of $\alpha=0.05$. Overall, the consumer purchasing behaviour towards Adidas was better than Puma guided by the social representation components queried in the study. 
Table 2: Attitude, Preference, and Behaviour of Consumers and E-Consumers towards Adidas T-Shirts and Shoes

\begin{tabular}{|c|c|c|c|c|c|c|c|c|c|c|c|}
\hline \multirow[b]{2}{*}{$\begin{array}{l}\frac{0}{0} \\
. \underline{I}\end{array}$} & \multirow[b]{2}{*}{ Items } & \multicolumn{5}{|c|}{ T-shirts } & \multicolumn{5}{|c|}{ Shoes } \\
\hline & & $\sum_{\Sigma}^{\Xi}$ & 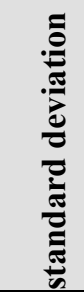 & 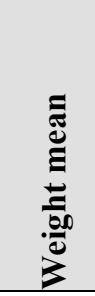 & 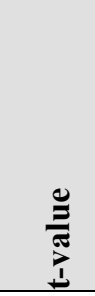 & 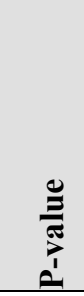 & $\sum_{\Sigma}^{\Xi}$ & 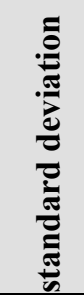 & 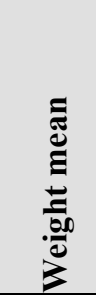 & 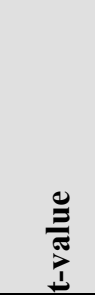 & 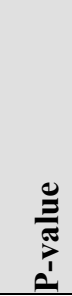 \\
\hline \multirow{3}{*}{$\underbrace{\stackrel{0}{E}}$} & $\begin{array}{l}\text { I have a positive outlook when } \\
\text { buying Adidas sportswear } \\
\text { brand from sports shops. }\end{array}$ & 3.26 & 0.97 & 81.56 & 13.31 & 0.00 & 3.39 & 0.92 & 84.82 & 16.17 & 0.00 \\
\hline & $\begin{array}{l}\text { I have a comfortable feeling } \\
\text { when I buy Adidas sportswear } \\
\text { brand }\end{array}$ & 2.97 & 1.11 & 74.21 & 7.16 & 0.00 & 3.06 & 1.08 & 76.45 & 8.58 & 0.00 \\
\hline & $\begin{array}{l}\text { When I buy Adidas sportswear } \\
\text { brand, I feel others respect me. }\end{array}$ & 3.21 & 1.02 & 80.33 & 11.80 & 0.00 & 2.89 & 1.07 & 72.18 & 6.02 & 0.00 \\
\hline \multicolumn{2}{|c|}{ Total } & 3.15 & 0.69 & 78.70 & 15.93 & 0.00 & 3.11 & 0.65 & 77.82 & 15.68 & 0.00 \\
\hline \multirow{3}{*}{ 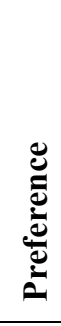 } & $\begin{array}{l}\text { I do buy Adidas sportswear } \\
\text { brand by myself. }\end{array}$ & 3.00 & 1.08 & 75.00 & 7.81 & 0.00 & 3.07 & 1.08 & 76.73 & 8.76 & 0.00 \\
\hline & $\begin{array}{l}\text { Purchasing Adidas sportswear } \\
\text { brand from the online store is } \\
\text { comfortable and enjoyable. }\end{array}$ & 2.94 & 1.08 & 73.60 & 6.93 & 0.00 & 3.04 & 1.08 & 75.91 & 8.26 & 0.00 \\
\hline & $\begin{array}{l}\text { I think it is beneficial to buy } \\
\text { Adidas sportswear brand from } \\
\text { online sports stores. }\end{array}$ & 3.01 & 1.09 & 75.26 & 7.89 & 0.00 & 3.07 & 1.09 & 76.82 & 8.70 & 0.00 \\
\hline \multicolumn{2}{|c|}{ Total } & 2.98 & 0.81 & 74.62 & 10.19 & 0.00 & 3.06 & 0.77 & 76.48 & 11.97 & 0.00 \\
\hline \multirow{2}{*}{ 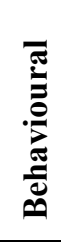 } & $\begin{array}{l}\text { I intend to buy Adidas } \\
\text { sportswear brand from online } \\
\text { stores. }\end{array}$ & 2.85 & 1.04 & 71.33 & 5.73 & 0.00 & 3.26 & 1.04 & 81.45 & 12.12 & 0.00 \\
\hline & $\begin{array}{l}\text { I intend to buy sportswear } \\
\text { Adidas brand from sports } \\
\text { shops. }\end{array}$ & 2.99 & 1.12 & 74.74 & 7.40 & 0.00 & 3.05 & 1.12 & 76.36 & 8.23 & 0.00 \\
\hline \multicolumn{2}{|c|}{ Total } & 2.92 & 0.89 & 73.03 & 8.03 & 0.00 & 3.16 & 0.78 & 78.91 & 13.97 & 0.00 \\
\hline 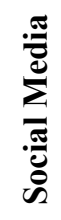 & $\begin{array}{l}\text { When purchasing Adidas } \\
\text { sportswear brand, I told my } \\
\text { friends across social media } \\
\text { network }\end{array}$ & 3.00 & 0.94 & 75.00 & 8.03 & 0.00 & 3.10 & 0.94 & 77.48 & 9.95 & 0.00 \\
\hline \multicolumn{2}{|c|}{ All items } & 3.03 & 0.50 & 75.69 & 17.75 & 0.00 & 3.10 & 0.49 & 77.58 & 20.45 & 0.00 \\
\hline
\end{tabular}


Table 3: Attitude, Preference, and Behaviour of Consumers and E-Consumers towards Puma T-Shirts and Shoes

\begin{tabular}{|c|c|c|c|c|c|c|c|c|c|c|c|}
\hline \multirow[b]{2}{*}{$\frac{\sigma}{0}$} & \multirow[b]{2}{*}{ Items } & \multicolumn{5}{|c|}{ T-shirts } & \multicolumn{5}{|c|}{ Shoes } \\
\hline & & 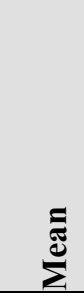 & 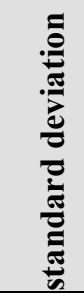 & 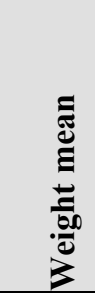 & 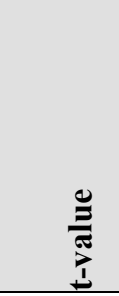 & 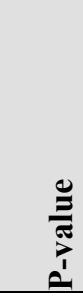 & $\sum_{\Sigma}^{\bar{J}}$ & 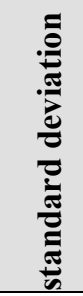 & 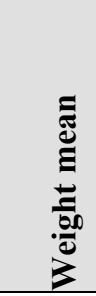 & 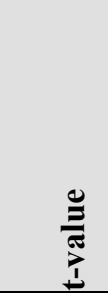 & 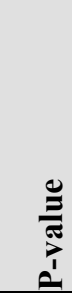 \\
\hline \multirow[b]{3}{*}{ 莺 } & $\begin{array}{l}\text { I have a positive } \\
\text { outlook when buying } \\
\text { Puma sportswear } \\
\text { brand from sports } \\
\text { shops. }\end{array}$ & 2.08 & 1.07 & 51.90 & -6.58 & 0.00 & 2.23 & 1.10 & 55.63 & -4.10 & 0.00 \\
\hline & $\begin{array}{l}\text { I have a comfortable } \\
\text { feeling when I buy } \\
\text { Puma sportswear } \\
\text { brand. }\end{array}$ & 2.18 & 1.01 & 54.53 & -5.26 & 0.00 & 2.06 & 0.93 & 51.57 & -7.70 & 0.00 \\
\hline & $\begin{array}{l}\text { When I buy Puma } \\
\text { sportswear brand, I } \\
\text { feel others respect me. }\end{array}$ & 1.80 & 1.03 & 45.11 & -11.19 & 0.00 & 1.61 & 0.88 & 40.22 & -16.61 & 0.00 \\
\hline \multicolumn{2}{|c|}{ Total } & 2.02 & 0.62 & 50.51 & -12.83 & 0.00 & 1.97 & 0.58 & 49.14 & -15.27 & 0.00 \\
\hline \multirow[b]{3}{*}{$\frac{\circlearrowright}{0}$} & $\begin{array}{l}\text { I do buy Puma } \\
\text { sportswear brand by } \\
\text { myself. }\end{array}$ & 2.13 & 1.05 & 53.26 & -5.83 & 0.00 & 1.99 & 0.99 & 49.82 & -8.45 & 0.00 \\
\hline & $\begin{array}{l}\text { Purchasing Puma } \\
\text { sportswear rand from } \\
\text { the online store is } \\
\text { comfortable and } \\
\text { enjoyable. }\end{array}$ & 2.28 & 0.94 & 56.97 & -3.89 & 0.00 & 2.22 & 0.88 & 55.54 & -5.22 & 0.00 \\
\hline & $\begin{array}{l}\text { I think it is beneficial } \\
\text { to buy Puma } \\
\text { sportswear brand from } \\
\text { online sports stores. }\end{array}$ & 2.00 & 1.10 & 50.00 & -7.54 & 0.00 & 1.85 & 1.04 & 46.13 & -10.41 & 0.00 \\
\hline \multicolumn{2}{|c|}{ Total } & 2.14 & 0.68 & 53.41 & -8.90 & 0.00 & 2.02 & 0.64 & 50.49 & -12.34 & 0.00 \\
\hline \multirow{2}{*}{ 苛 } & $\begin{array}{l}\text { I intend to buy Puma } \\
\text { sportswear brand from } \\
\text { online stores. }\end{array}$ & 2.23 & 0.95 & 55.80 & -4.68 & 0.00 & 2.18 & 0.88 & 54.43 & -6.03 & 0.00 \\
\hline & $\begin{array}{l}\text { I intend to buy Puma } \\
\text { sportswear brand from } \\
\text { sports shops. }\end{array}$ & 2.00 & 1.12 & 50.09 & -7.38 & 0.00 & 1.84 & 1.05 & 46.03 & -10.32 & 0.00 \\
\hline \multicolumn{2}{|c|}{ Total } & 2.12 & 0.61 & 52.94 & -10.43 & 0.00 & 2.01 & 0.56 & 50.23 & -14.51 & 0.00 \\
\hline 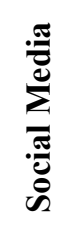 & $\begin{array}{l}\text { When purchasing } \\
\text { Puma sportswear } \\
\text { brand, I told my } \\
\text { friends across social } \\
\text { media network }\end{array}$ & 2.52 & 1.18 & 63.01 & 0.26 & 0.80 & 2.51 & 1.19 & 62.68 & 0.09 & 0.93 \\
\hline \multicolumn{2}{|c|}{ All items } & 2.13 & 0.43 & 53.20 & -14.28 & 0.00 & 2.04 & 0.40 & 51.01 & -19.07 & 0.00 \\
\hline
\end{tabular}

\subsection{Frequency of Shopping}

Consumers and e-consumers regularly shopped for Adidas t-shirts and shoes than similar brands of Puma in respective sports shops as shown in the bar graph in Figure 1 below 


\section{How regularly do you shop in store for Adidas and Puma shoes and t-shirts?}

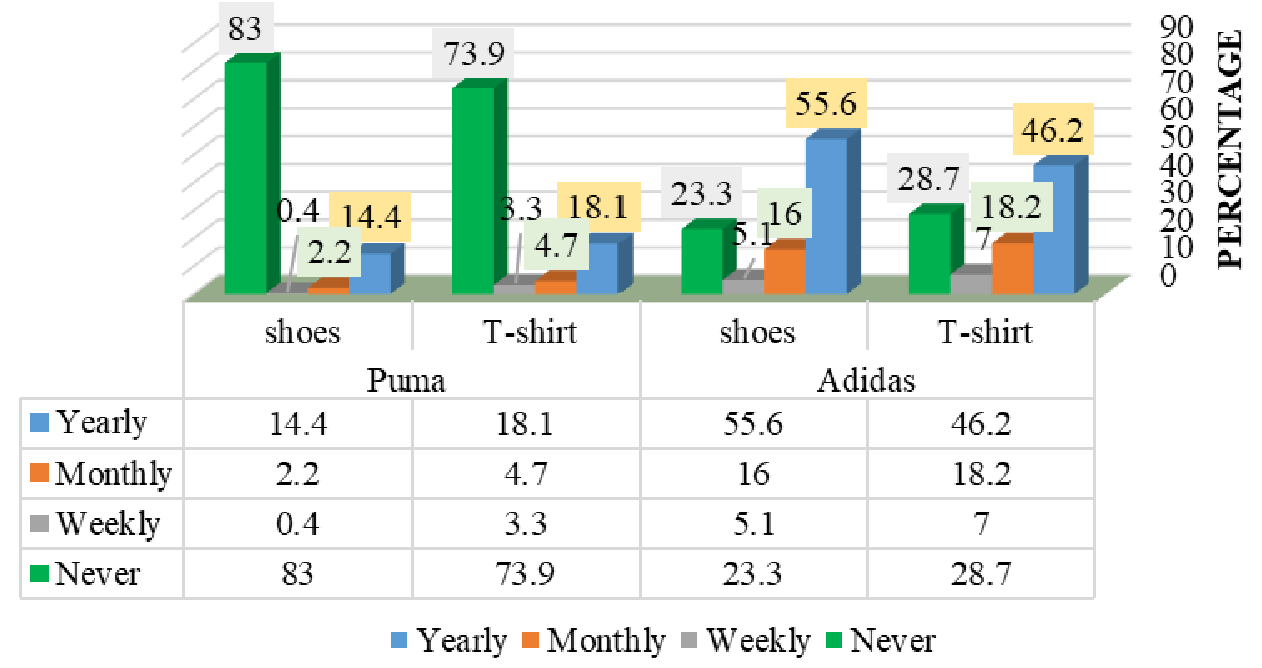

Figure 1: Shopping Patterns for Adidas and Puma Sportswear Brands in Their Sports Shops

Consumers and e-consumers buy more t-shirts and shoes from Adidas than they do from Puma's online shops, as shown in Figure 2 below.

\section{How regularly do you shop online for Adidas and Puma shoes and t- shirts?}
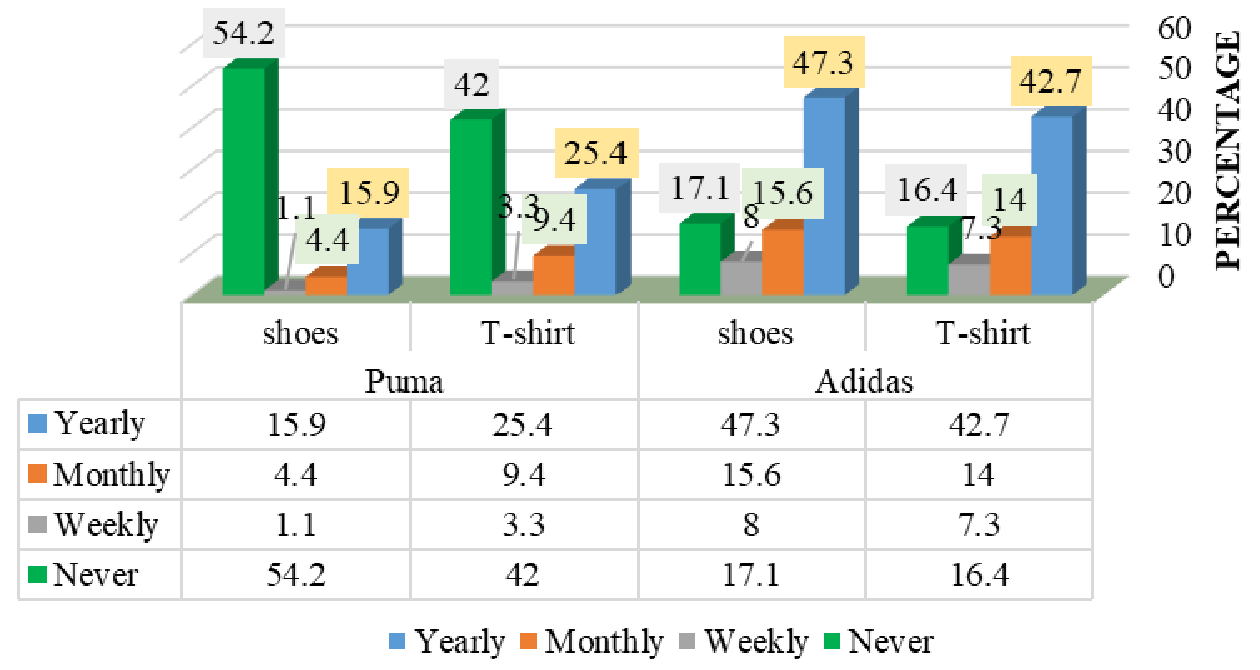

Figure 2: Shopping Patterns for Adidas and Puma Sportswear Brands in their Online Shops

Buying online and in-store were mediating factors for the respondents of different age, living area, gender, and educational level.

\section{Discussion}

The preference for purchasing valuable sportswear products increased with the social representation created by either Adidas or Puma. Components such as quality, efficiency, efficacy, expensive nature, or benefits increase the intention to purchase from sports shops or online stores. The findings reflected the findings of Pyone and Isen (2018) when they assessed the influences of consumers' willingness to purchase a product. The social representations cement the positive affect, high-level thinking, and intertemporal choices. O'Guinn, Tanner, and Maeng (2015) argue that physical stores enhance the value the customers associate with valuable brands. The spaces increase the desire for product valuation, which varies from one social class to another. Furthermore, a correlation emerged between social media networks, attitudes, behavioural intentions, and preferences for Adidas and Puma's shoes and t-shirts. Adidas registered higher preference due to the higher social media input 
observed from the e-consumers and customers visiting sports shops.

Consumer-brand relationships develop in the social media environment. The research confirmed how both consumers and e-consumers increase their preference and positive attitudes towards Adidas more than Puma depending on the social media branding made. The findings align with the principles of parasocial interaction theory (PSI) that Labrecque (2014) associated with willingness and loyalty to brands. However, firms must maintain high interactivity and open communication to evoke high social media response to brands by either econsumers or normal consumers. Godey et al. (2016) terms social media activities as the source of the influence require for brand equity creation and the consumer behaviours towards a particular brand. Adidas and Puma fostered a varying level of social media response due to the different degree of awareness and images by registered customers on social media sites.

The study further affirmed the link between attitude and preferences for either Adidas or Puma t-shirts and shoes among consumers and e-consumers. The consumers can buy at the sports shops or online platforms while e-consumers can shop at the in-stores depending on the packaging of the brands. The findings align with the outcomes of another research by Choi et al. (2010) on consumer preferences for fast fashion brands. Key factors determine positive attitudes, including brand loyalty, perceived quality, self-image, involvement, product features, and brand concept similarities. However, Kacen, Hess, and Kevin Chiang (2013) argue that online stores enhance brand selection or variety more than brick and mortar stores that face uncertainty due to handling charges.

Saudi Arabian consumers and e-consumers increase their purchasing intentions towards Adidas more than Puma due to the perceived social class. Brands gain prominence when the luxury goods signal status. Issues such as conspicuousness of the logo can increase the association level for wealthy individuals than other groups (Han, Nunes, \& Drèze, 2010). The preference for brands that reflect high status transcends consumers buying from the stores and online shops. Consequently, consumers purchase genuine brands as opposed to counterfeits because they protect their social hierarchies and identities (Amaral \& Loken, 2016). Hence, in-group preferences can arise among consumers of varying age, gender, living area, or educational level.

Gender age, living area, and education increase the behavioural intention of e-consumers and normal consumers for Adidas or Puma t-shirts and shoes. Stores can boost purchases when they align with the choices of the clientele and personal lifestyles. On the other hand, consumers and e-consumers demonstrate different behavioural intentions, preferences, and attitudes when either buying from in-stores or online. The representations of the outlets determine brand association, loyalty, and return purchases. Cho and Workman (2011) insist on the prominence of stores having a blend of social class, opinion leadership touch, and fashion innovativeness more than product variety or fashion quality offered by the e-commerce stores. Conversely, Jones and Kim (2010) argue that online stores can foster retail brand trust and purchase intention when paired with estore patronage website quality, clothe involvement, and offline patronage.

Mediating factors such as social class and attitude influenced the purchasing in the stores or online. The social class and attitudes of consumers determine the behavioural intentions of the consumers aiming to associate with a given brand. Lee, Ko, and Megehee (2015) found that luxury and non-luxury self-display of brands should improve the status and display of wealth. Branding to shape the meet the expectations of social classes and attitudes is imperative for brands such as Adidas and Puma. The firms have brand logos that signal status during human social representations. $\mathrm{He}, \mathrm{Li}$, and Harris (2012) argue that aligning with the social identity perspective of the customers should foster brand loyalty through identity and identification.

Adidas and Puma drove consumer purchases because the brands satisfied the desired they expected from the valuable sportswear brands. Customers build their brand loyalty when organisations meet their needs at the stores or eCommerce platforms (Sung \& Kim, 2010; Bian \& Moutinho, 2011). The loyalty towards brands manifests through behaviours and attitudes. Customers visiting physical stores or purchasing their brands through eCommerce centres can recommend the brands to their families, friends, or relatives because of the perceived value they have received over time. However, Su and Tong (2015) opine that firms should sustain the personality of the brands through direct and indirect interactions with consumers. Connecting with the personality of consumers from different social classes can foster purchasing intentions, consumption, and repeat purchases.

Influencing consumer behaviour in the era of social media demands proper brand placement (Popp \& Woratschek, 2016). Adidas and Puma have penetrated the growing market of Saudi Arabia due to the understanding of brand placement. The two companies have transcended the mediating factors such as social class, demographics, and location of the consumers. Understandably, brand placement positions as the solution every customer need (Van Reijmersdal, Smit, \& Neijens, 2010). The process appeals to the consumer perceptions and awareness level of the brand.

\section{Conclusion}

The study confirms the varying consumer purchasing behaviours towards brands in the apparel industry from a 
social representation perspective. The comparative analysis of Saudi's e-consumers and in-store consumers helps to understand how companies such as Adidas and Puma package their brands so that behavioural intentions align with social representation components, attitudes, and preferences. Customers and e-consumers consider factors such as quality, benefits, convenient, signalled status, or effectiveness when purchasing their valuable sportswear brands from online stores or sports shops. Adidas fostered a higher consumer purchasing behaviour towards its tshirts and shoes among its consumers and e-consumers than the moderate effect found on Puma's brands. Online and offline stores, social class, age, gender, living areas, and educations moderate the purchasing behaviours towards valuable sportswear brands.

The demand for valuable and branded sports apparel in Saudi Arabia will continue to grow as the country undergoes significant changes in technological advancement. ECommerce has redefined behavioural intention towards Saudi Arabian-based brands, namely Adidas and Puma, but with apparent differences among customers of different demographics. The penetration of internet retailing indicates significant change in the branding process for firms that want to capitalise on both in-store and online shopping experiences to drives sales. Primarily, the study affirmed that companies should target different segments including the youths who have driven majority of the online sales for both Puma and Adidas. Every company will aim at changing the way Saudi consumers make their choices, preferences, and transform their lifestyles using valuable brands such as tshirts and shoes.

Managers should track the consumption of brand wear consumptions to understand how social representation perspective influences adoption by customers. The purchase of footwear and apparel is no longer dependent on pricing along, but the impression the consumers are set to make in their social scenes. The Saudi Arabian consumers buying valuable sportswear brands from the internet or in-stores have proven that consumption can vary based on experience. Consequently, consumption will indicate the effort a company has injected to influence purchase decision-making and loyalty to their brands. Social representation perspective emerged as a vital element in understanding how consumers perceive equity aspects such as quality association, and awareness about its ability to meet individual or social needs. Tracking brand consumption will improve brand knowledge, image, and need for increasing awareness in the market.

The study prompts marketers to package brands as social markers on the sports shops, online stores, and social media to align with different clientele. The brand's personality should resonate with the needs of every age group, living area, gender, social class, and preferences on social media. Hence, establish an appropriate marketing mix to enhance preference and positive attitudes towards brands is essential and an avenue for informing behavioural intentions. Brand presence in Saudi Arabia will be vital so that brands resonate with the different consumer segments with diverse purchasing behaviours. Further research should concentrate on determining consumer purchasing behaviours towards other sportswear brands rather than Adidas or Puma from the standpoint of social representation model.

\section{References}

Abalkhail, T. S. (2017). The Attitudes of Saudi Youth Toward U.S. Apparel Brand Names. Journal of International Consumer Marketing, 30(1), 58-68. doi:10.1080/08961530.2017.1376242

Abosag, I., \& Farah, M. (2014). Religiously Motivated Consumer Boycott: The Impact on Brand Image, Product Judgment and Customer Loyalty. The Sustainable Global Marketplace, 167-167. doi:10.1007/978-3-31910873-5 86

Aghekyan-Simonian, M., Forsythe, S., Suk Kwon, W., \& Chattaraman, V. (2012). The role of product brand image and online store image on perceived risks and online purchase intentions for apparel. Journal of Retailing and Consumer Services, 19(3), 325-331. doi:10.1016/j.jretconser.2012.03.006

Al-Ghaith, W., Sanzogni, L., \& Sandhu, K. (2010). Factors Influencing the Adoption and Usage of Online Services in Saudi Arabia. The Electronic Journal of Information Systems in Developing Countries, 40(1), 132. doi:10.1002/j.1681-4835.2010.tb00283.x

Alhazzaa, Thamer. (2014). Saudi eBay Project: eBusiness, eCommerce and eAuction in Saudi Arabia development of an online auction platform. München: GRIN Verlag GmbH. Retrieved from: http://nbnresolving.de/urn:nbn:de:101:1-2015041912659.

Amaral, N. B., \& Loken, B. (2016). Viewing usage of counterfeit luxury goods: Social identity and social hierarchy effects on dilution and enhancement of genuine luxury brands. Journal of Consumer Psychology, 26(4), 483-495. doi:10.1016/j.jcps.2016.02.004

Azam, A. (2015). Investigation of psychological dimensions of trust on e-loyalty: A case of Saudi Arabia consumers. Journal of Islamic Marketing, 6(2), 224-249. doi:10.1108/jima-12-2013-0083

Bian, X., \& Moutinho, L. (2011). The role of brand image, product involvement, and knowledge in explaining consumer purchase behaviour of counterfeits. European Journal of Marketing, 45(1/2), 191-216. doi:10.1108/03090561111095658

Bilgihan, A. (2016). Gen Y customer loyalty in online shopping: An integrated model of trust, user experience 
and branding. Computers in Human Behavior, 61, 103-113. doi:10.1016/j.chb.2016.03.014

Birks, M., \& Mills, J. (2015). Grounded Theory: A Practical Guide. Thousand Oaks, CA: SAGE.

Biscaia, R., Correia, A., Rosado, A. F., Ross, S. D., \& Maroco, J. (2013). Sport Sponsorship: The Relationship Between Team Loyalty, Sponsorship Awareness, Attitude Toward the Sponsor, and Purchase Intentions. Journal of Sport Management, 27(4), 288-302. doi:10.1123/jsm.27.4.288

Biscaia, R., Correia, A., Ross, S., \& Rosado, A. (2014). Sponsorship effectiveness in professional sport: an examination of recall and recognition among football fans. International Journal of Sports Marketing and Sponsorship, 16(1), 2-18. doi:10.1108/ijsms-16-01-2014-b002

Blasco-Arcas, L., Hernandez-Ortega, B., \& Jimenez-Martinez, J. (2014). The online purchase as a context for co-creating experiences. Drivers of and consequences for customer behavior. Internet Research, 24(3), 393412. doi:10.1108/intr-02-2013-0023

Busnaina, I. (2014). Fashion Marketing in Arab World: Maintaining Brand Identity vs. Adaptation. Wilson College of Textiles, $9(1)$.

Cheung, C. M., Xiao, B. S., \& Liu, I. L. (2014). Do actions speak louder than voices? The signaling role of social information cues in influencing consumer purchase decisions. Decision Support Systems, 65, 50-58. doi:10.1016/j.dss.2014.05.002

Chi, T., \& Kilduff, P. P. (2011). Understanding consumer perceived value of casual sportswear: An empirical study. Journal of Retailing and Consumer Services, 18(5), 422-429. doi:10.1016/j.jretconser.2011.06.004

Cho, S., \& Workman, J. (2011). Gender, fashion innovativeness and opinion leadership, and need for touch. Journal of Fashion Marketing and Management: An International Journal, 15(3), 363-382. doi:10.1108/13612021111151941

Choi, T., Liu, N., Liu, S., Mak, J., \& To, Y. (2010). Fast fashion brand extensions: An empirical study of consumer preferences. Journal of Brand Management, 17(7), 472-487. doi:10.1057/bm.2010.8

Dabholkar, P. A., \& Sheng, X. (2012). Consumer participation in using online recommendation agents: effects on satisfaction, trust, and purchase intentions. The Service Industries Journal, 32(9), 1433-1449. doi:10.1080/02642069.2011.624596

Darrat, M. (2011). A conceptual investigation into the effects of cultural animosity on Middle Eastern consumers' purchase intentions. Journal of Islamic Marketing, 2(1), 5-13. doi:10.1108/17590831111115204

Eng, T., \& Bogaert, J. (2010). Psychological and cultural insights into consumption of luxury Western brands in India. Journal of Customer Behaviour, 9(1), 55-75. doi:10.1362/147539210x497620

Euromonitor International. (2019, March 1). Sportswear in Saudi Arabia. Retrieved from http://www.euromonitor.com/sportswear-in-saudi-arabia/report

Godey, B., Manthiou, A., Pederzoli, D., Rokka, J., Aiello, G., Donvito, R., \& Singh, R. (2016). Social media marketing efforts of luxury brands: Influence on brand equity and consumer behavior. Journal of Business Research, 69(12), 5833-5841. doi:10.1016/j.jbusres.2016.04.181

Godey, B., Pederzoli, D., Aiello, G., Donvito, R., Chan, P., Oh, H., ... Weitz, B. (2012). Brand and country-oforigin effect on consumers' decision to purchase luxury products. Journal of Business Research, 65(10), 1461-1470. doi:10.1016/j.jbusres.2011.10.012

Han, Y. J., Nunes, J. C., \& Drèze, X. (2010). Signaling Status with Luxury Goods: The Role of Brand Prominence. Journal of Marketing, 74(4), 15-30. doi:10.1509/jmkg.74.4.15

Handa, M., \& Khare, A. (2011). Gender as a moderator of the relationship between materialism and fashion clothing involvement among Indian youth. International Journal of Consumer Studies, 37(1), 112-120. doi:10.1111/j.1470-6431.2011.01057.x

He, H., Li, Y., \& Harris, L. (2012). Social identity perspective on brand loyalty. Journal of Business Research, 65(5), 648-657. doi:10.1016/j.jbusres.2011.03.007

Herhausen, D., Binder, J., Schoegel, M., \& Herrmann, A. (2015). Integrating Bricks with Clicks: Retailer-Level and Channel-Level Outcomes of Online-Offline Channel Integration. Journal of Retailing, 91(2), 309-325. doi:10.1016/j.jretai.2014.12.009

Herrmann, J., Kacha, M., \& Derbaix, C. (2016). “I support your team, support me in turn!”: The driving role of consumers' affiliation with the sponsored entity in explaining behavioral effects of sport sponsorship leveraging activities. Journal of Business Research, 69(2), 604-612. doi:10.1016/j.jbusres.2015.05.016

Hoyer, W. D., MacInnis D. J., \& Pieters R. (2013). Consumer behavior. Australia: South Western Cengage Learning.

Huang, Y., \& Huddleston, P. (2009). Retailer premium own-brands: creating customer loyalty through own-brand products advantage. International Journal of Retail \& Distribution Management, 37(11), 975992. doi:10.1108/09590550910999389

Jones, C., \& Kim, S. (2010). Influences of retail brand trust, off-line patronage, clothing involvement and website quality on online apparel shopping intention. International Journal of Consumer Studies, 34(6), 627-637. doi:10.1111/j.1470-6431.2010.00871.x 
Kacen, J. J., Hess, J. D., \& Kevin Chiang, W. (2013). Bricks or Clicks? Consumer Attitudes toward Traditional Stores and Online Stores. Global Economics and Management Review, 18(1), 12-21. doi:10.1016/s23401540(13)70003-3

Khare, A., Mishra, A., Parveen, C., \& Srivastava, R. (2011). Influence of consumers' susceptibility to interpersonal influence, collective self-esteem and age on fashion clothing involvement: A study on Indian consumers. Journal of Targeting, Measurement and Analysis for Marketing, 19(3-4), 227-242. doi:10.1057/jt.2011.22

Kilambi, A., Laroche, M., \& Richard, M. (2013). Constitutive marketing: Towards understanding brand community formation. International Journal of Advertising, 32(1), 45-64. doi:10.2501/ija-32-1-045-064

Kim, A. J., \& Ko, E. (2010). Impacts of Luxury Fashion Brand's Social Media Marketing on Customer Relationship and Purchase Intention. Journal of Global Fashion Marketing, 1(3), 164-171. doi:10.1080/20932685.2010.10593068

Kim, J., Kim, K. H., Garrett, T. C., \& Jung, H. (2015). The Contributions of Firm Innovativeness to Customer Value in Purchasing Behavior. Journal of Product Innovation Management,32(2), 201-213. doi:10.1111/jpim.12173

Ko, E., Taylor, C. R., Sung, H., Lee, J., Wagner, U., Navarro, D. M., \& Wang, F. (2012). Global marketing segmentation usefulness in the sportswear industry. Journal of Business Research, 65(11), 1565-1575. doi:10.1016/j.jbusres.2011.02.041

Labrecque, L. I. (2014). Fostering Consumer-Brand Relationships in Social Media Environments: The Role of Parasocial Interaction. Journal of Interactive Marketing, 28(2), 134-148. doi:10.1016/j.intmar.2013.12.003

Lapan, S. D., Quartaroli, M. T., \& Riemer, F. J. (2011). Qualitative Research: An Introduction to Methods and Designs. Hoboken, NJ: John Wiley \& Sons.

Lee, J., Ko, E., \& Megehee, C. M. (2015). Social benefits of brand logos in presentation of self in cross and same gender influence contexts. Journal of Business Research, 68(6), 1341-1349. doi:10.1016/j.jbusres.2014.12.004

Lim, J., Al-Aali, A., \& Heinrichs, J. H. (2014). Impact of satisfaction with e-retailers' touch points on purchase behavior: the moderating effect of search and experience product type. Marketing Letters, 26(2), 225-235. doi:10.1007/s11002-014-9334-x

Mazodier, M., \& Merunka, D. (2014). Beyond brand attitude: Individual drivers of purchase for symbolic cobranded products. Journal of Business Research, 67(7), 1552-1558. doi:10.1016/j.jbusres.2014.01.015

Närvänen, E., \& Goulding, C. (2016). Sociocultural brand revitalization. European Journal of Marketing, 50(7/8), 1521-1546. doi:10.1108/ejm-05-2014-0328

O’Guinn, T. C., Tanner, R. J., \& Maeng, A. (2015). Turning to Space: Social Density, Social Class, and the Value of Things in Stores. Journal of Consumer Research, ucv010. doi:10.1093/jcr/ucv010

Olbrich, R., \& Holsing, C. (2011). Modeling Consumer Purchasing Behavior in Social Shopping Communities with Clickstream Data. International Journal of Electronic Commerce, 16(2), 15-40. doi:10.2753/jec10864415160202

Park, C., \& Lee, T. M. (2009). Information direction, website reputation and eWOM effect: A moderating role of product type. Journal of Business Research, 62(1), 61-67. doi:10.1016/j.jbusres.2007.11.017

Patten, M. L. (2016). Questionnaire Research: A Practical Guide. London, England: Routledge.

Popp, B., \& Woratschek, H. (2016). Introducing branded communities in sport for building strong brand relations in social media. Sport Management Review, 19(2), 183-197. doi:10.1016/j.smr.2015.06.001

Prendergast, G. P., Tsang, A. S., \& Chan, C. N. (2010). The interactive influence of country of origin of brand and product involvement on purchase intention. Journal of Consumer Marketing, 27(2), 180-188. doi: $10.1108 / 07363761011027277$

Pyone, J. S., \& Isen, A. M. (2011). Positive Affect, Intertemporal Choice, and Levels of Thinking: Increasing Consumers' Willingness to Wait. Journal of Marketing Research,48(3), 532-543. doi:10.1509/jmkr.48.3.532

Rahman, M., Albaity, M., Isa, C. R., \& Azma, N. (2018). Towards a better understanding of fashion clothing purchase involvement. Journal of Islamic Marketing, 9(3), 544-559. doi:10.1108/jima-03-2017-0028

Reimann, M., Castaño, R., Zaichkowsky, J., \& Bechara, A. (2012). How we relate to brands: Psychological and neurophysiological insights into consumer-brand relationships. Journal of Consumer Psychology, 22(1), 128-142. doi:10.1016/j.jcps.2011.11.003

Sheth, J. N., \& Mittal, B. (2004). Customer behavior: A managerial perspective, 2nd ed. Mason:Thomson South-Western

Shukla, P. (2009). Impact of contextual factors, brand loyalty and brand switching on purchase decisions. Journal of Consumer Marketing, 26(5), 348-357. doi:10.1108/07363760910976600

$\mathrm{Su}, \mathrm{J} .$, \& Tong, X. (2015). Brand personality and brand equity: evidence from the sportswear industry. Journal of Product \& Brand Management, 24(2), 124-133. doi:10.1108/jpbm-01-2014-0482 
Suki, N. M. (2013). Students' demand for smartphones. Campus-Wide Information Systems, 30(4), 236-248. doi:10.1108/cwis-03-2013-0013

Sung, Y., \& Kim, J. (2010). Effects of brand personality on brand trust and brand affect. Psychology and Marketing, 27(7), 639-661. doi:10.1002/mar.20349

Tong, X., \& Su, J. (2014). Exploring the personality of sportswear brands. Sport, Business and Management: An International Journal, 4(2), 178-192. doi:10.1108/sbm-08-2012-0032

Urquhart, C. (2012). Grounded Theory for Qualitative Research: A Practical Guide. Thousand Oaks, CA: SAGE.

Van Reijmersdal, E., Smit, E., \& Neijens, P. (2010). How media factors affect audience responses to brand placement. International Journal of Advertising, 29(2), 279-301. doi:10.2501/s0265048710201154 